\title{
Choosing the method of excavating vein reserves and mineralized zones on the basis of simulation modeling
}

\author{
Konstantin Strukov ${ }^{1}$, Irina Nikiforova ${ }^{1 *}$, Vladimir Lavenkov ${ }^{1}$ and Yuri Iun $^{1}$ \\ ${ }^{1}$ Institute of Complex Exploitation of Mineral Resources of the Russian Academy of Sciences. \\ Moscow, Russia
}

\begin{abstract}
For the effective involvement of off-balance ores into development, a simulation modeling of gross and selective mining variants at "Kochkar" deposit reserves has been carried out by the Monte Carlo method, provided that a new type of geological resource - mineralized rocks has been involved in mining, and an economic evaluation of competing options has been made. Keywords: "Kochkar" deposit, underground mining, excavation method, selective and gross mining technologies, Monte Carlo method, ore veins, mineralization zones, poor ore raw stock.
\end{abstract}

\section{Introduction}

An analysis of negative trends in the state of the mineral wealth sector of Russia shows that their main reason is the wide use in the mining sector of the concept on extensive subsoil use, which led to a significant deterioration in the quality and primary specifications of the mineral wealth of most mineral deposits. To the full, this refers to the development of veined gold ore deposits in the South Urals, for which the uneven nature of the distribution of minerals in the solid mass of the deposit predetermined the initial selective excavation of rich sites and the abandonment of ore reserves with low quality characteristics.

According to current forecasts, given the existing scale of production, the availability of gold reserves for underground mining in the region is 20-30 years, open - 30-40 years [1]. However, taking into account the increase in the production capacity of mines and the retirement of the facilities of existing enterprises, the supply of the sector will drop sharply, which will bring the region closer to the critical level of the state of the ore gold resource portfolio.

The generalization of the experience of exploitation of gold deposits, developed by "Yuzhuralzoloto Group of Companies", OJSC ("YuGK", OJSC), specializing in the extraction and treatment of gold-bearing ores and metallurgical manufacturing of commercial gold, allowed justifying the concept and identify the principles of preserving the production potential of the mining engineering system in the conditions of reducing volume of reproduction of the resource portfolio and falling quality specifications of the mined ore, as well as increasing mining depth. In order to prevent the liquidation of the

\footnotetext{
"Corresponding author: nikiforova495@mail.ru
} 
enterprise and, as a consequence, the emergence of a set of socioeconomic and environmental problems, fundamentally new geotechnological solutions have been adopted aimed at changing the technology of mining and treatment of gold-bearing ores with subsequent disposal of waste in the developed subsoil area [2-6]. That will ensure the stabilization of not only the economic, but also the geomechanical and ecological situation [7].

One of the principles of the new concept is full disclosure of the potential of the resource portfolio, rejecting of the initial selective testing of the richest sites of deposits and transition to joint development of gold ore veins and adjacent mineralized zones. The fulfillment of this condition allows, by increasing the vertical capacity of ore deposits, to increase the intensity of the cleaning works, to apply more productive development systems with mass breaking of ore, to involve hard sites of deposits, with a small and highly variable gold content in the ore, and also to move to deeper horizons, where "traditional", previously used technologies become less profitable, or unprofitable.

To date, the reserves of vein deposits and mineralized host rocks that were previously abandoned during the initial development due to the economic inexpediency of mining have not been considered as promising for involvement in the development.

Analysis of the gold content in veins and in host rocks, applied to the conditions of development of the "Kochkar" deposit, showed that on the worked out horizons there are promising sections of veins and mineralized rocks, in terms of size and techno-economic conditions suitable for development. These reserves include mineralization zones in the hanging and lying sides of gold ore veins (tabashka), as well as in quartz-flooded granites. The thickness of such ores reaches 10-14 m, with an average gold content of $3 \mathrm{~g} / \mathrm{t}$. In connection with the growth of prices for precious metals, the cleaning-up of these mineralization has become profitable. For their work out, a system has been introduced for the development of sub-floor drifts with borehole breaks, which has made it possible to increase labor productivity at the stoped excavation and to reduce the prime cost of the extracted ore mass [8-10].

In turn, the need to take into account the specifics of the technological schemes for processing ore raw materials of rich veins and mineralized rocks required a set of research works aimed at justifying the parameters of high-performance development systems, choosing the preferred option for mining rich ore reserves and cutting mineralized zones and identifying the economic feasibility of applying various methods of excavating ore veins and mineralized zones: a comparison of the selective working of the vein with gross simultaneous extraction of all the stocks of the mineralized zones and veins included in the chamber contour.

\section{Methodology}

To select the best option for excavating ore in areas including veins and mineralization zones, a simulated Monte Carlo modeling of gross and selective excavation was performed. The comparative evaluation was carried out according to two criteria: the mass of extracted gold and the resulting specific profit per 1 ton of recoverable reserves for the options considered.

During the simulation, variants of the stepwise selective excavation of rich ores with their separate extrusion onto the surface for self-processing of the extracted ore mass by cyanidation with different gold contents were considered. Also, the options with gross development of ore veins and mineralized zones with varying gold content in veins and mineralized rocks were considered.

As initial data for the construction of the probability model, the gold extraction parameters were used depending on the base gold content in the ore, provided that the 
extracted ore mass was processed by cyanidation at the Artem completed enrichment cycle factory. Economic indicators of ore mass redistribution at this factory were adopted during the modeling. A general view of the probabilistic model, which reflects the dependence of the recovery index on the gold content, is shown in Fig. 1 and is described by the expression:

$$
\varepsilon=100 \cdot\left(\frac{\alpha}{|\alpha|+d}+\delta\right),
$$

where $\varepsilon$-extraction parameter, $\% ; \alpha$-gold content, $\mathrm{g} / \mathrm{t} ; \delta$ - sporadic error of the model; $d$ - model's parameter.

a)

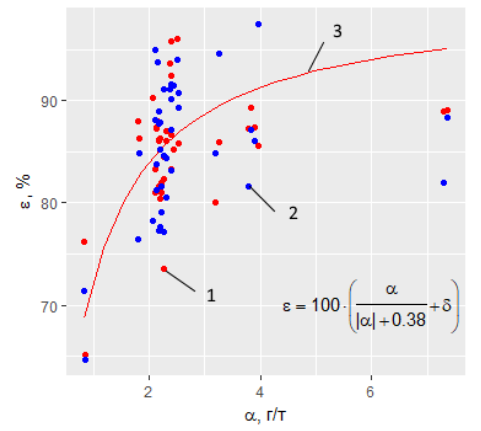

б)

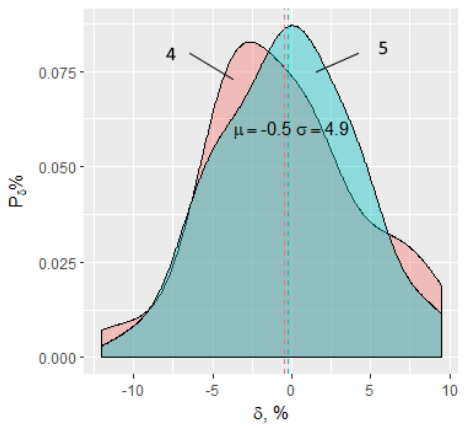

Fig. 1: $a$ - Regression model of the dependence of gold recovery in leaching on the gold content in ore: 1 - observational data; 2 - model-generated data; 3 - graph of the regression model; $b$ - error distribution density of the regression model: 4 - according to observation data; 5 - software-generated results

In Fig. 1, position 1 shows the points obtained from the data of actual observations, position 3 - the results of model processing obtained by regression analysis. Fig. 1b shows the error distribution density for the actual data (4), the values of its mathematical expectation $(\mu)$ and standard deviation $(\sigma)$ are presented, on the basis of which the sporadic error was programmed (5). Based on the regression model (3) and the error distribution density (5), recovery indices were generated depending on the gold content (2).

In the future, the regression model of gold recovery from the extracted ore mass was used to programmatically generate the gold recovery parameter from the extracted ore mass by cyanidation taking into account the error, which included the identification of the mass of recovered gold per 1 ton of extracted ore mass for the options of selective and gross working of veins and mineralized rocks .

This experiment assumed the generation of initial values of gold content in veins and mineralized rocks, their combination, the generation of the recovery index for each combination according to the formula (1), the calculation of the specific gravity of extracted gold for two options of working out $\left(M e_{g r}\right.$ and $\left.M e_{s e l}\right)$ according to formulas (2) and (3), as well as their difference ( $\Delta M e$ ), calculated according to (4). This algorithm was implemented in the model 100 times, and for each combination of gold content in the vein and mineralized rocks, the probability $P_{m e}$ was calculated that the mass of extracted gold for the selective production option would be higher than the mass for the gross extraction.

$$
\begin{aligned}
& M e_{\text {вал }}=\frac{1-\Pi_{\text {кам }}}{1+P_{\text {кам }}} \cdot \bar{\alpha} \cdot \varepsilon_{-}, \mathrm{g} / \mathrm{t} ; \\
& M e_{\text {gr }}=1-L_{\text {cham }} / 1+D_{\text {cham }} * \bar{\alpha} * \varepsilon_{\bar{\alpha}} / \mathrm{g} / \mathrm{t} ;
\end{aligned}
$$




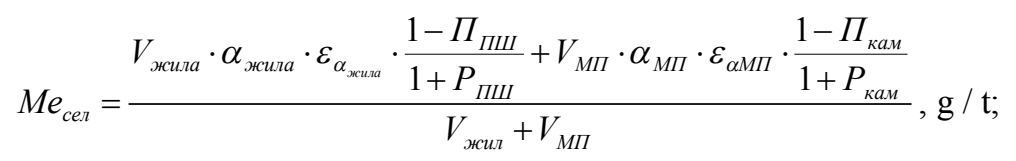

$$
\begin{aligned}
& M e_{\text {sel }}=V_{\text {vein }} * \alpha_{\text {vein }} * \varepsilon_{\alpha}^{- \text {vein }} * 1-L_{s f l} / 1+D_{s f l}+V_{m r} * \alpha_{m r} * \varepsilon_{\alpha}^{-} m r * 1-L_{c h a m} / \\
& 1+D_{\text {cham }} \\
& \Delta M e=M e_{s e l}-M e_{g r}, \mathrm{~g} / \mathrm{t},
\end{aligned}
$$

where $\bar{\alpha}$ - weighted average content of gold in the ore block, $\mathrm{g} / \mathrm{t} ; \alpha_{\text {vein }}$ and $\alpha_{\mathrm{mr}}-$ gold content in vein and mineralized rocks, $\mathrm{g} / \mathrm{t}$; $\mathrm{V}_{\text {vein }}=1 * \mathrm{~h} * \mathrm{~m}_{\text {vein }}$ and $\mathrm{V}_{\mathrm{mr}}=1 * \mathrm{~h} * \mathrm{~m}_{\mathrm{mr}}-$ volume of vein and mineralized rocks in the block, respectively, $\mathrm{m}^{3} ; h$ and $l$ - height and width of the block, $\mathrm{m} ; \varepsilon_{\alpha}$-extraction of gold from ores in gross mining, unit fraction; $\varepsilon_{\alpha}^{-}$vein and $\varepsilon_{\alpha}^{-} \mathrm{mr}-$ extraction of gold from vein and mineralized rocks in selective mining, unit fraction; $L_{\text {cham }}, D_{\text {cham }}, L_{s f l}$ and $D_{s f l}$ - loss and dilution of ore under systems of chamber and sub-floor drifts, unit fraction.

Weighted average content of gold in the ore block:

$$
\begin{aligned}
& \bar{\alpha}=\frac{V_{\text {жсила }} \cdot \alpha_{\text {жкила }}+V_{\text {МП }} \cdot \alpha_{\text {мП }}}{V_{\text {жсила }}+V_{\text {МП }}} \\
& \bar{\alpha}=V_{\text {veіп }} * \alpha_{\text {vein }}+V_{m r} * \alpha_{m r} / V_{\text {vein }}+V_{m r}
\end{aligned}
$$

Similarly, the probability $\left(P_{p r}\right)$ was calculated that, with the selective extraction option, the profit would be higher than with the gross mining, respectively. The profit for selective and gross options of mining was found by the formulae:

$$
\begin{aligned}
& \operatorname{Pr}_{\text {уд сел }}=M e_{\text {сел }} \cdot Ц_{\text {золота }}-\left(C_{\text {ПНР ПШ сел }}+C_{\text {ПНР кам сел }}+C_{\text {заки сел }}+C_{\text {обог селл }}\right), \\
& \operatorname{Pr}_{\text {sp sel }}=M e_{\text {sel }} * P_{\text {gold }}-\left(C_{P O D \text { sfl sel }}+C_{P O D \text { cham sel }}+C_{\text {fill sel }}+C_{\text {enr sel }}\right) \\
& \operatorname{Pr}_{\text {уд вал }}=M e_{\text {вал }} \cdot Ц_{\text {золота }}-\left(C_{\text {ПНР кам вал }}+C_{\text {закл вал }}+C_{\text {обог вал }}\right) \text {, } \\
& P r_{s p ~ g r}=M e_{g r} * P_{\text {gold }}-\left(C_{P O D \text { cham } g r}+C_{\text {fill gr }}+C_{\text {enr gr }}\right) \\
& \triangle P r=\Delta \operatorname{Pr}_{s p s e l}-\triangle \operatorname{Pr}_{s p g r}
\end{aligned}
$$

The cost of preparatory-development operations (PDO) for a system of sub-floor drifts in selective mining was defined as:

$$
\begin{gathered}
C_{\text {ПНР ПШ сел }}=\frac{C_{\text {ПНР ПШ }} \cdot V_{\text {жила }}}{V_{\text {жила }}+V_{\text {МП }}} \cdot \frac{1-\Pi_{\text {ПШ }}}{1+P_{\text {ПШ }}}, \\
C_{P O D \text { sfl sel }}=C_{P O D s f l} * V_{\text {vein }} / V_{\text {vein }}+V_{m r} * 1-L_{s f l} / 1+D_{s f l}
\end{gathered}
$$

where $\mathrm{C}_{\mathrm{POD} \text { sfl }}$ - cost of PDO for a system of sub-floor drifts per 1 ton of mined ore mass, rubles/t.

Cost of PDO for a chamber system in selective mining was defined as:

$$
\begin{gathered}
C_{\text {ПНР кам сел }}=\frac{C_{\text {ПНР кам }} \cdot V_{\text {МП }}}{V_{\text {жила }}+V_{\text {МП }}} \cdot \frac{1-\Pi_{\text {кам }}}{1+P_{\text {кам }}}, \\
C_{P O D \text { cham sel }}=C_{P O D \text { cham }} * V_{m r} / V_{\text {vein }}+V_{m r} * 1-L_{\text {cham }} / 1+D_{\text {cham }}
\end{gathered}
$$

where $\mathrm{C}_{\mathrm{POD} \text { cham }}$ - cost of PDO for a chamber system, per 1 ton of mined ore mass, rubles/t. 
Cost of filling operations accounting for underfilling factor and loss/dilution in gross mining option is assessed as:

$$
C_{\text {fill sel }}=\left(1-L_{\text {cham }}\right) *\left(1+D_{\text {cham }}\right) *\left(1-L_{s f l}\right) *\left(1+D_{s f f}\right) * k_{u f} * C_{\text {fill }}
$$

where $\mathrm{C}_{\text {fill }}-$ cost of filling operations per 1 ton of mined ore mass, rubles/t.

Cost of enrichment per 1 ton of ore in block:

$$
\begin{gathered}
V_{\text {жила }} \cdot\left(1-\Pi_{\text {ПШ }}\right) \cdot\left(1+P_{\text {ПШ }}\right) \cdot C_{\text {обог жил } 1 m}+ \\
C_{\text {обог сел }}=\frac{+V_{\text {МП }} \cdot\left(1-\Pi_{\text {кам }}\right) \cdot\left(1+P_{\text {кам }}\right) \cdot C_{\text {обог мП } 1 m}+}{V_{\text {жсила }}+V_{\text {МП }}} \\
C_{\text {enr sel }}=V_{\text {vein }} *\left(1-L_{\text {sfl }}\right) *\left(1+L_{\text {sff }}\right) * C_{\text {enr vein } 1 t}+V_{m r} *\left(1-L_{\text {cham }}\right) *(1+ \\
\left.L_{\text {cham }}\right) * C_{\text {enr mr lt }}+/ V_{\text {vein }}+V_{m r}
\end{gathered}
$$

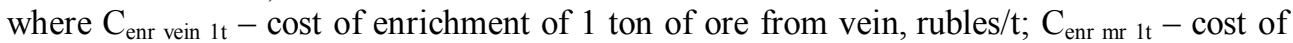
enrichment of 1 ton of ore from mineralized rocks, rubles/t.

Cost of PDO for chamber system in gross mining:

$$
\begin{aligned}
C_{\text {ПНР кам вал }} & =C_{\text {ПНР кам }} \cdot \frac{1-\Pi_{\text {кам }}}{1+P_{\text {кам }}} . \\
C_{P O D \text { cham gr }} & =C_{P O D \text { cham }} * 1-L_{\text {cham }} / 1+D_{\text {cham }}
\end{aligned}
$$

Cost of filling operations accounting for underfilling factor and loss/dilution in gross mining option is assessed as:

Cost of enrichment per 1 ton of ore in block:

$$
C_{\text {fill gr }}=\left(1-L_{\text {cham }}\right) *\left(1+L_{\text {cham }}\right) * k_{u f}+C_{\text {fill }}
$$

$$
C_{\text {enr } g r}=\left(1-L_{\text {cham }}\right) *\left(1+L_{\text {cham }}\right) * C_{\text {enr vein-mr } 1 t} \text {. }
$$

\begin{tabular}{|c|c|c|c|}
\hline Parameters & Symbol & Unit & Value \\
\hline Block length & $l$ & $\mathrm{~m}$ & 60 \\
\hline Block height & $h$ & $\mathrm{~m}$ & 60 \\
\hline Loss in sub-floor drift systems & $L_{s f l}$ & unit fraction & 0.11 \\
\hline Dilution in sub-floor drift systems & $D_{s f l}$ & unit fraction & 0.10 \\
\hline Loss in chamber systems & $L_{\text {cham }}$ & unit fraction & 0.15 \\
\hline Dilution in chamber systems & $D_{\text {cham }}$ & unit fraction & 0.15 \\
\hline Gold price & $P_{\text {gold }}$ & rubles & 2,480 \\
\hline Underfilling factor & $k_{u f}$ & unit fraction & 0.95 \\
\hline Cost of filling mixture per 1 ton of mined ore mass & $C_{\text {fill }}$ & rubles/t & 382.80 \\
\hline $\begin{array}{l}\text { Cost of preparatory-development operations for a } \\
\text { system of sub-floor drifts per } 1 \text { ton of mined ore } \\
\text { mass }\end{array}$ & $C_{P D O \text { sfl }}$ & rubles/t & $1,121.92$ \\
\hline $\begin{array}{l}\text { Cost of preparatory-development operations for a } \\
\text { chamber system per } 1 \text { ton of mined ore mass }\end{array}$ & $C_{P D O \text { cham }}$ & rubles/t & 518 \\
\hline $\begin{array}{l}\text { Cost of enrichment of } 1 \text { ton of averaged ore from } \\
\text { veins and mineralized rocks }\end{array}$ & $\begin{array}{c}C_{\text {enr vein-mr }} \\
\text { It }\end{array}$ & rubles/t & 700 \\
\hline Cost of enrichment of 1 ton of vein gold & $C_{\text {enr vein } 1 t}$ & rubles/t & 700 \\
\hline
\end{tabular}

where $C_{\text {enr vein-mr } 1 \mathrm{t}}$ - cost of enrichment of 1 ton of averaged ore from veins and mineralized rocks, rubles/t.

\section{Results and Discussion}

As the initial data for geotechnological modeling, the extraction and enrichment indicators achieved at the "Kochkar" underground mine (Table 1) were adopted.

Table 1. Initial data of geotechnological modeling 


\begin{tabular}{|c|c|c|c|}
\hline Parameters & Symbol & Unit & Value \\
\hline Cost of enrichment of 1 ton of mineralized rocks & $C_{\text {enr mr } 1 t}$ & rubles/t & 700 \\
\hline
\end{tabular}

Fig. 2 presents in the form of diagrams the results of calculating the probability of preferred selective extraction based on the maximum profit criteria and the maximum gold extraction for various values of gold content in ore and zones adjacent to the vein as the thickness of veins and mineralized rocks varies. Taking into account the influence of the contrast of the gold content in the ore mass on the factors of maximum profit and maximum extraction of gold, the areas of preference for the use of selective excavation have been identified (dark color selection in the graph).

a)

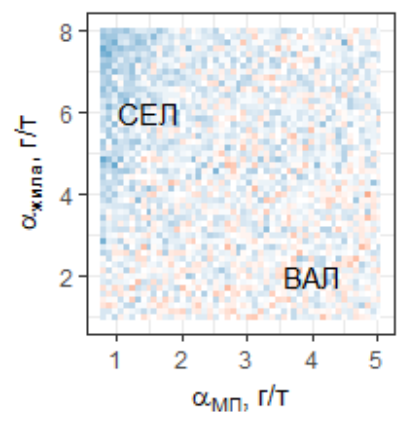

\begin{tabular}{|c|c|}
\hline$\Gamma / \mathrm{T}$ & $\mathrm{g} / \mathrm{t}$ \\
\hline CEЛ & SEL \\
\hline BAЛ & GR \\
\hline УБЫT & LOSS \\
\hline д.e. & unit fraction \\
\hline
\end{tabular}

b)

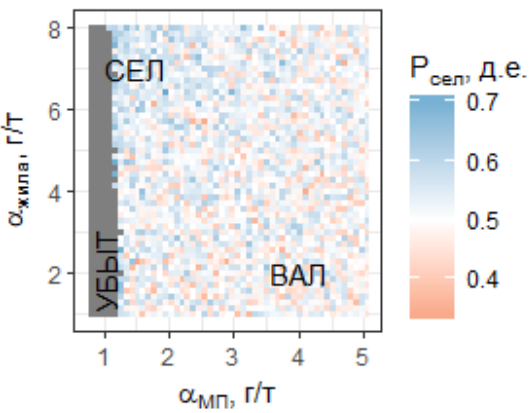

Fig. 2. Diagrams of the probability of preferring the use of selective technology of mining in comparison with the gross method by the criterion: $a$ - recoverable gold; $b$ - maximizing the corporate profit

An analysis of the data in Fig. 2 allows drawing a conclusion that for ranges of gold content in veins from $1 \mathrm{~g} / \mathrm{t}$ to $8 \mathrm{~g} / \mathrm{t}$ and in mineralized rocks from $0.7 \mathrm{~g} / \mathrm{t}$ to $3 \mathrm{~g} / \mathrm{t}$, respectively, the preferred technology is gross extraction, both by the criterion of maximum metal extraction and by the criterion of profit.

a)

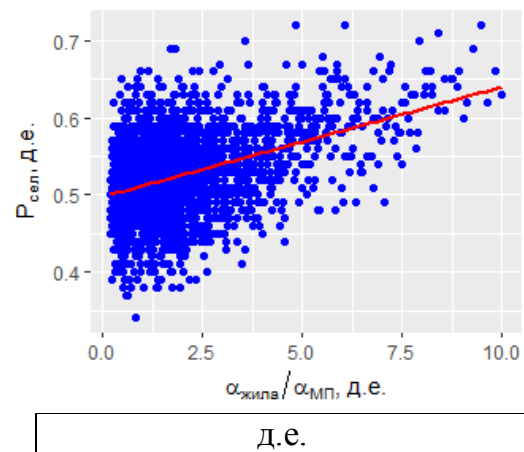

б)

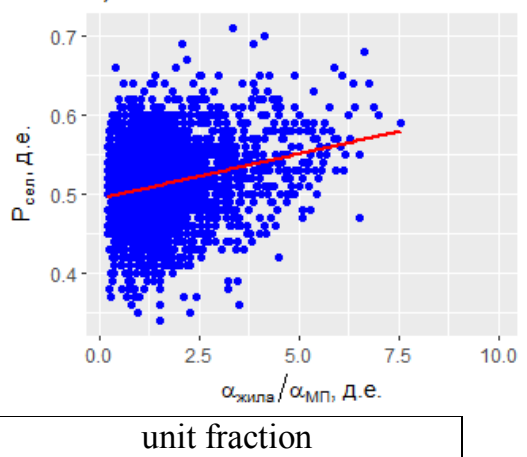

Fig. 3. Probability of the effectiveness of applying selective extraction method depending on the contrast of the contents by the criterion: $a$ - recoverable gold; $b$ - maximizing the corporate profit 
The influence of the contrast of the average gold content in the vein and the adjacent mineralized zone on the area of preferential application of selective extraction for different values of the vein and mineralized rock thickness by these factors is shown in Fig. 3. An analysis of the diagrams presented in Fig. 3, allows concluding that as the contrast of the content of ores increases $\left(\alpha_{\text {vein }} / \alpha_{\mathrm{mr}}\right)$, the probability of effective application of the selective extraction method also increases.

\section{Conclusions}

On the example of "Kochkar" deposit, for the first time for the conditions of involving a new kind of geological resource - mineralized rocks of vein gold deposits - at the final stage of exploitation of balance reserves, the efficiency of gross and selective excavation of goldbearing ore mass was compared on the basis of geological testing of ore veins and mineralized zones. As shown by the comparison of the options performed, with the current level of gold prices and the existing difference in production costs for gross and selective excavation, the difference in the processing of rich and poor ores is not compensated by a change in production costs in the extraction methods under consideration. When the content of gold in veins and adjacent mineralized zones is up to 8 and the thickness of the veins is up to $1 \mathrm{~m}$, gross excavation of ore is preferred at the final stage of underground mining of vein gold deposits in the South Urals. Selective excavation is expedient only at high contrast of gold content in the vein and adjacent mineralized zones - above 8, vein thickness more than $1.5 \mathrm{~m}$ and thickness of mineralized zones less than $10 \mathrm{~m}$.

\section{References}

1. Cencerning the state and use of mineral resources in the Russian Federation in 2015: State report / Moscow: the Ministry of Natural Resources and Ecology of the Russian Federation, 2015. URL: http://www.mnr.gov.ru/upload/iblock/c50/2015_msr.pdf.

2. K.N. Trubetskoy, Development of resource-saving and resource-reproducing geotechnologies for the integrated development of mineral deposits. Moscow: IPKON RAS. 2014. - p. 196.

3. N.N. Melnikov. Jubilee session of the Department of Geology, Geophysics, Geochemistry and Mining Sciences of Russian Academy of Sciences "Development of new scientific directions and technologies for the development of the earth interior". FSUE National Science Center for Mining Production. Skochinsky Institute of Mining. 24-26. (2000)

4. D.R. Kaplunov, D.N. Radchenko. Mining Magazine. 11. 52-59. (2017)

5. V.N. Kalmykov, K.I. Strukov, G.P. Konstantinov, R.V. Kulsaitov. Bulletin of the Nosov Magnitogorsk State Technical University. 14 (3). 13-20. (2016)

6. D.J. Packey. Resour. Policy. 37 (1). 104-108. (2012)

7. V.N. Kalmykov et al. Eurasian mining. 2. 12-15. (2017)

8. K.I. Strukov, V.V. Fedoseev, R.V. Berger, M.V. Rylnikova. Mining Magazine. 6. 5-8. (2017)

9. M.V. Rylnikova, I.L. Nikiforova, V.A. Yezhov, S.N. Plotnikov. Mining Magazine. 9. 35-40. (2017)

10. K.I. Strukov, M.V. Rylnikova, I.L. Nikiforova. Mining Industry. 2. 46-49. (2018) 